\title{
Impact of Work Motivation, Compensation, and Working Environment on Employee Performance at PT. Kawai Indonesia
}

\author{
Ignatius Oktafa Ika Fordamea ${ }^{1}$, Ahmad Badawi Saluy ${ }^{2}$ \\ \{oktafa1981@yahoo.co.id', ahmad.badawi@mercubuana.ac.id²\} \\ Universitas Mercu Buana, Jakarta, Indonesia ${ }^{12}$
}

\begin{abstract}
This study discusses motivation, compensation, and environment on Employee Performance at PT. Kawai Indonesia both partially and simultaneously. The method used is a quantitative method with the type of associative research. The population in this study were all employees of PT. Kawai Indonesia. The sample method used is probability sampling with sampling techniques using simple random sampling. The data analysis method uses multiple linear regression analysis with the help of SPSS software program version 24.00. The results showed that some of these studies had a positive effect on the performance of the employees of PT. Kawai Indonesia. Compensation of a significant positive effect on the performance of employees of PT. Kawai Indonesia. Positive work environment significantly on the performance of employees of PT. Kawai Indonesia. Simultaneously work motivation, compensation, and work environment together significantly influence the performance of employees of PT. Kawai Indonesia.
\end{abstract}

Keywords: Motivation, Compensation, Work Environment, Employee Performance

\section{Introduction}

The human resources needed in a company must of course have high quality work. This can be demonstrated by the ability of employees to achieve good performance in the company. Based on previous studies conducted by Tahmeem Siddiqi and Sadia Tangem [1], Evangeline and Thavakumar [2] in Annual International Research Conferenceit is suspected that the factors affecting employee performance are work environment, compensation, and work motivation. The problem that the company is currently experiencing, one of which is not optimal for employee performance, this is due to the repeated employees' mistakes have made, causing the performance measurement indicators to be unfulfilled. There is a decline in the phenomenon of designed performance at PT. Kawai Indonesia then conducted preresearch, which aims to identify what factors are causing the employee's performance to decline.

Pre-research involved 30 employees of PT Kawai Indonesia with the research variables namely motivation, compensation and the work environment using the questionnaire. Further pre-research results are presented in the following table 1,2,3 and 4: 
Table 1. Results of The Motivation Variable

\begin{tabular}{|c|c|c|c|c|c|c|}
\hline \multirow{2}{*}{ No } & \multirow{2}{*}{ Question } & \multicolumn{4}{|c|}{ Percentage } & \multirow{2}{*}{$\begin{array}{c}\text { Total } \\
\text { Respondents }\end{array}$} \\
\hline & & $\mathrm{Ag}$ & & Dis & gree & \\
\hline 1 & $\begin{array}{l}\text { I feel motivated by the career development } \\
\text { provided by the company }\end{array}$ & 8 & $27 \%$ & 22 & $73 \%$ & 30 \\
\hline 2 & $\begin{array}{c}\text { My boss cares about my work and always } \\
\text { pushes to develop }\end{array}$ & 17 & $57 \%$ & 13 & $43 \%$ & 30 \\
\hline 3 & $\begin{array}{l}\text { I feel motivated by giving assignments and } \\
\text { bonuses }\end{array}$ & 11 & $37 \%$ & 19 & $63 \%$ & 30 \\
\hline 4 & $\begin{array}{l}\text { I feel motivated after getting awards and } \\
\text { praise from superiors }\end{array}$ & 25 & $83 \%$ & 5 & $17 \%$ & 30 \\
\hline 5 & I tried hard to be the best among friends & 14 & $47 \%$ & 16 & $53 \%$ & 30 \\
\hline
\end{tabular}

From table 1, results of pre-research can be known that there are 22 employees $(73 \%)$ Of the total respondents who feel that the company's policy does not provide good career development for its employees. Where employees feel career, development is only aimed at certain people such as Non indigenous, IMM graduates and employees who possess Japanese language.

Table 2 The Result of Compensation Variable

\begin{tabular}{|c|c|c|c|c|c|c|}
\hline \multirow{2}{*}{ No } & \multirow{2}{*}{ Question } & \multicolumn{4}{|c|}{ Percentage } & \multirow{2}{*}{$\begin{array}{c}\text { Total } \\
\text { Respondents }\end{array}$} \\
\hline & & Agre & & Dis & gree & \\
\hline 1 & $\begin{array}{l}\text { I am satisfied with the existing wage } \\
\text { scale structure in the company }\end{array}$ & 8 & $27 \%$ & 22 & $73 \%$ & 30 \\
\hline 2 & $\begin{array}{l}\text { I am satisfied with the award given by } \\
\text { the company }\end{array}$ & 9 & $30 \%$ & 21 & $70 \%$ & 30 \\
\hline 3 & $\begin{array}{l}\text { Payments of salaries per month have } \\
\text { never been delayed }\end{array}$ & 30 & $100 \%$ & 0 & $0 \%$ & 30 \\
\hline 4 & $\begin{array}{l}\text { the existing compensation system has } \\
\text { been transparent }\end{array}$ & 21 & $70 \%$ & 9 & $30 \%$ & 30 \\
\hline 5 & $\begin{array}{l}\text { The allowance provided by the company } \\
\text { is in accordance with the principle of } \\
\text { fairness }\end{array}$ & 25 & $83 \%$ & 5 & $17 \%$ & 30 \\
\hline
\end{tabular}

Source: Results of pre-research on 30 employees of PT Kawai Indonesia (October 2019)

From table 2, results of pre-research can be noted that there are 22 employees $(73 \%)$ Of the total respondents who were dissatisfied with the salary loudness reflected in the company's wage structure, and 18 employees $(60 \%)$ Of the total respondents who were dissatisfied with the facilities provided by the company.

Table 3. The Results of Work Environment Variables

\begin{tabular}{|c|c|c|c|c|c|c|}
\hline \multirow{2}{*}{ No } & \multirow{2}{*}{ Question } & \multicolumn{4}{|c|}{ Percentage } & \multirow{2}{*}{$\begin{array}{c}\text { Total } \\
\text { Respondents } \\
\end{array}$} \\
\hline & & Agr & & Dis & gree & \\
\hline 1 & $\begin{array}{l}\text { I feel comfortable with the work } \\
\text { atmosphere in the company }\end{array}$ & 7 & $23 \%$ & 23 & $77 \%$ & 30 \\
\hline 2 & $\begin{array}{l}\text { I feel the condition of the company's work } \\
\text { environment is conducive }\end{array}$ & 14 & $47 \%$ & 16 & $53 \%$ & 30 \\
\hline 3 & $\begin{array}{l}\text { I feel that the facilities provided by the } \\
\text { company are in accordance with the work }\end{array}$ & 20 & $67 \%$ & 10 & $33 \%$ & 30 \\
\hline
\end{tabular}




\begin{tabular}{|c|c|c|c|c|c|c|}
\hline 4 & $\begin{array}{l}\text { security at work has made me work } \\
\text { comfortably }\end{array}$ & 17 & $57 \%$ & 13 & $43 \%$ & 30 \\
\hline 5 & $\begin{array}{l}\text { I have a good relationship with colleagues } \\
\text { and superiors }\end{array}$ & 16 & $53 \%$ & 14 & $47 \%$ & 30 \\
\hline
\end{tabular}

Source: Results of pre-research on 30 employees of PT Kawai Indonesia (October 2019)

From table 3, results of pre-study can be noted that there are 23 employees (77\%) Of the total respondents who felt uncomfortable with the workplace atmosphere within the company, subsequently, as many as 16 employees (53\%) Of the total respondents who feel the current working environment is not conducive.

Table 4. The Result of Performance Variable

\begin{tabular}{|c|c|c|c|c|c|c|}
\hline \multirow{2}{*}{ No } & \multirow{2}{*}{ Question } & \multicolumn{4}{|c|}{ Percentage } & \multirow{2}{*}{$\begin{array}{c}\text { Total } \\
\text { Respondents } \\
\end{array}$} \\
\hline & & Ag1 & & Dis & gree & \\
\hline 1 & $\begin{array}{l}\text { I have never made a mistake in doing } \\
\text { work }\end{array}$ & 16 & $53 \%$ & 14 & $47 \%$ & 30 \\
\hline 2 & I can finish more work than targeted & 23 & $77 \%$ & 7 & $23 \%$ & 30 \\
\hline 3 & I have knowledge of the work that I do & 27 & $90 \%$ & 3 & $10 \%$ & 30 \\
\hline 4 & $\begin{array}{l}\text { I have the responsibility and } \\
\text { commitment to work }\end{array}$ & 28 & $93 \%$ & 2 & $7 \%$ & 30 \\
\hline 5 & $\begin{array}{l}\text { I try to achieve the work targets set by } \\
\text { the company }\end{array}$ & 19 & $63 \%$ & 11 & $37 \%$ & 30 \\
\hline
\end{tabular}

Source: Results of pre-research on 30 employees of PT Kawai Indonesia (October 2019)

The results of table 4 pre-study can be seen that there are 14 employees $(47 \%)$ have made mistakes on goods or negligence which results in goods not having good quality (Pokamisu). Thus, it can be concluded that the current performance condition of PT Kawai Indonesia's employees not yet optimal, it can be seen from the high number of Pokamisu where in 2017 there were 110 and in 2018 there were 132 of the targets set, namely 50.

\subsection{Literature Review}

\subsubsection{Motivation work}

According to Herzberg [3], [4] work motivation is a person's attitude towards his job in order to create a sense of satisfaction with his performance. According to Edwin B Flippo (in Malayu Hasibuan [5]) states that motivation is a skill, in directing employees and organizations to work successfully, so that employees and organizational goals are achieved at the same time [6], [7].

\subsubsection{Compensation}

Compensation what is said to be fair does not mean that every employee receives adequate compensation just as big. But based on the principle of justice, whether in judgment, treatment, giving gifts, and punishment for each employee. So that the principle of justice will create a good working atmosphere, work motivation, discipline, loyalty, and better employee stability. In the book Donni Juni Priansa [8]. 


\subsubsection{Work Environment}

According to Barry Render \& Jay Heizer [9], [10], the work environment is a physical environment where employees work which affects their performance, safety and quality of work life. A conducive work environment provides a sense of security and allows employees to work optimally. The work environment can affect employee emotions, if the employee likes the work environment where he works, then the employee will feel at home in the workplace to carry out activities so that work time is used effectively and optimally, employee work performance is also high [11].

\subsubsection{Employee performance}

Performance is a picture of the achievements of the company in its operational activities both related to the financial aspects, marketing aspects, aspects of raising funds and channeling funds, aspects of technology, and aspects of human resources [12], [13], [14] Fachreza, Musnadi and Majid, 2018). Performance is the result of work that has a strong relationship with the organization's strategic objectives, customer satisfaction, and contributes to the economy [15], [16], [17]. Dessler [18], [19], argues that employee performance (work performance) is the employee's actual achievement compared to the expected performance of the employee.

\section{Research Method}

The research approach used in research is a quantitative research approach with an explanative or causal design. This research is a cross-sectional study, which is a type of research that collects information / questionnaires only once at a time. The data to be used in this research are primary data and secondary data. The population used in this study were all employees who were employees of PT. Kawai Indonesia, amounting to 272 people. In the sampling and population, the failure rate (e) $5 \%$ is used, which means the level of confidence / level of confidence is $95 \%$. The number of samples used in this study were 162 employees. The sample selection used probability sampling method with simple random sampling technique, where the researcher distributed the questionnaire directly to the respondents who were selected to be the sample. So that the respondents obtained as many as 162 employees. Data analysis was performed with multiple linear regression using the SPSS version 24.00 software program.

\section{Results and Discussion}

\subsection{Results}

The objects in this study are all outsourcing employees who are employees of PT. Kawai Indonesia, amounting to 162 employees. The characteristics of respondents in this study can be seen in the following description.

Table 5. Characteristics of Respondents by Gender

\begin{tabular}{ccccc}
\hline & & Frequency & Percent & Valid Percent \\
\hline Valid & Man & 120 & 74 & 74 \\
& Woman & 42 & 26 & 26 \\
& Total & 162 & 100 & \\
\hline
\end{tabular}

Source: Primary data processed (2020 
It is known that the majority of respondents were male as many as 120 respondents $(74.1 \%)$ and the remaining 42 respondents $(25.9 \%)$ stated that they were female.

Table 6. Characteristics of Respondents by Age

\begin{tabular}{ccccc}
\hline & & Frequency & Percent & Valid Percent \\
\hline Valid & $18-30$ th & 95 & 58,6 & 58,6 \\
& $31-40$ th & 40 & 24,6 & 24,6 \\
& $41-50$ th & 23 & 14,1 & 14,1 \\
$51-57$ th & 4 & 2,7 & 2,7 \\
Total & 162 & 100 & \\
\hline
\end{tabular}

Respondents who stated aged 20-30 years were 95 respondents (56.6\%). Then the respondents who stated age $31-40$ years as many as 40 respondents $(24.6 \%)$. While respondents who stated that they were $41-50$ years old were 24 respondents $(14.1 \%)$ and the remaining 4 respondents $(2.7 \%)$ stated that they were over 50 years old.

Table 7. Characteristics of Respondents Based on Education

\begin{tabular}{ccccc}
\hline & & Frequency & Percent & Valid Percent \\
\hline \multirow{6}{*}{ Valid } & SMP & 5 & 3 & 3 \\
& SMK & 128 & 79 & 79 \\
& D3 & 12 & 7,4 & 7,4 \\
& S1 & 15 & 9,3 & 9,3 \\
& S2 & 2 & 1,3 & 1,3 \\
& TOTAL & 162 & 100 & \\
\hline
\end{tabular}

Source: Primary data processed (2020)

It can be seen that respondents who stated their last education $<$ SLTA were 5 respondents (3\%). Then the respondents who stated their last high school / vocational education 128 respondents $(79 \%)$. While the respondent who stated their last education was D3, 12 respondents $(7.4 \%)$. Furthermore, respondents who stated their last education S1 were 15 respondents (9.3\%). And respondents who stated their last education was S2 2 respondents $(1.3 \%)$.

\subsection{Discussion}

Based on the results of the validity test that has been carried out on 162 respondents. It is known that each question on the variables of work motivation, compensation, work environment and employee performance shows that the calculated $r$ value is greater than $r$ table $(0.153)$ meaning the data is valid. The results of the reliability test of each variable have a Cronbach's alpha value greater than 0.5 so that the data is reliable or trustworthy. After testing the validity and reliability, the researcher conducts a normality test to see whether in the regression model, confounding or residual variables have a normal distribution. The data normality test in this study will be carried out by the Kolmogorov-Smirnov test, where the data is said to be normal if the significant value is greater than 0.05 .

Table 8. Normality Test Results

\begin{tabular}{ccc}
\hline \multicolumn{2}{c}{ One-Sample Kolmogorov-Smirnov Test } \\
\hline $\mathrm{N}$ & Unstandardized Residual \\
Normal Parameter's & .0000000 & 162 \\
& & $0 \mathrm{E}-7$
\end{tabular}




$\begin{array}{ccc} & .22836677 & 3,31766712 \\ \text { Most Extreme Differences } & .121 & , 081 \\ & .117 & , 043 \\ \text { Kolmogorov-Smirnov Z } & -.121 & -, 081 \\ \text { Asymp. Sig. (2-tailed) } & 1.121 \\ \text { a. Test distribution is Normal. } & .321 \mathrm{c} \\ \text { b. Calculated from data. } & \\ \text { buth } & \end{array}$

The Kolmogorov-Smirnov value is 1.121 and the significance is 0.321 . The significance value obtained is greater than 0.05 . Then it can be concluded that the data in the regression model is normally distributed.

Table 9. Multicollinearity Test Results

\begin{tabular}{lll}
\hline Variable & Tolerance & VIF \\
\hline Work Motivation & 0,580 & 1,724 \\
Compensation & 0,572 & 1,749 \\
Work Environment & 0,591 & 1,692 \\
\hline Source: Results of Data Processing with SPSS $24(2020)$
\end{tabular}

It can be seen that the three independent variables obtain a tolerance value $>0.10$ and the VIF value for the three independent variables $<10$. Thus, the results of this test indicate that work motivation, compensation, and work environment do not correlate with each other or there is no multicollinearity in the regression model.

Table 10. Heteroscedasticity Test Results

\begin{tabular}{llll}
\hline No. & Variable & Sig. & Kesimpulan \\
\hline 1. & Work Motivation & 0,341 & No Heteroscedasticity Occurs \\
2. & Compensation & 0,421 & No Heteroscedasticity Occurs \\
3. & Work Environment & 0,602 & No Heteroscedasticity Occurs \\
\hline \multicolumn{2}{l}{ Source: }
\end{tabular}

Heteroskedasticity test results showed a significant value obtained by the variable work motivation, compensation, and work environment greater than 0.05 . So that the three variables are free from heteroscedasticity problem.

Table 11. Multiple Regression Test Results Coefficients

\begin{tabular}{|c|c|c|c|c|c|c|}
\hline & \multirow[t]{2}{*}{ Model } & \multicolumn{2}{|c|}{ Unstandardized Coefficients } & \multirow{2}{*}{$\begin{array}{c}\begin{array}{c}\text { Standardized } \\
\text { Coefficients }\end{array} \\
\text { Beta }\end{array}$} & \multirow[t]{2}{*}{$\mathrm{t}$} & \multirow[t]{2}{*}{ Sig. } \\
\hline & & $\mathrm{B}$ & Std. Error & & & \\
\hline \multirow{4}{*}{1} & (Constant) & 0,086 & 0,186 & & 0,463 & 0,644 \\
\hline & R_MK & 0,585 & 0,052 & 0,575 & 11,188 & 0,000 \\
\hline & R_KOM & 0,238 & 0,050 & 0,247 & 4,771 & 0,000 \\
\hline & R_LK & 0,158 & 0,045 & 0,181 & 3,556 & 0,000 \\
\hline
\end{tabular}


a. Dependent Variable: KK

The results of the regression equation on the significance of the coefficient and interpretation of the regression equation are as follows: Constant values $(a)=0.086$; which states that if the existence of the work environment, compensation and work motivation does not exist or is 0 , then the performance of employees is 0.086 . Work Motivation $(\mathrm{MK})=$ 0.585; which means that if there is an increase in the work motivation variable by 1 unit, the employee's performance will increase by 0.585 . Compensation $(\mathrm{KOM})=0.238$; which means that if there is an increase in the compensation variable by the 1 unit, the employee's performance will increase by 0.238 . Work Environment $(\mathrm{LK})=0.158$; which means that if there is an increase in the work environment variable by the1 unit, then employee performance will increase by 0.15 .

Table 12. Partial Hypothesis Test Results (t Test)

\begin{tabular}{cccc}
\hline No & Variable & T & Sig. \\
\hline 1. & Work Motivation & 11,188 & 0,000 \\
2. & Compensation & 4,771 & 0,000 \\
3. & Work Environment & 3,556 & 0,000 \\
\hline
\end{tabular}

Based on Table 9 can be explained about the results of the $t$ test hypothesis as follows:

\subsubsection{Work Motivation}

$\mathrm{T}$ count value of $11.188>\mathrm{t}$-table 1.975 with a significant value (sig.) Of $0.000<0.05$. It can be concluded that work motivation has a significant effect on the employee's performance of PT. Kawai Indonesia.

\subsubsection{Compensation}

$\mathrm{T}$ count value of $4.771>$ t-table 1.975 with a significant value (sig.) Of $0.000<0.05$. It can be concluded that the Work Compensation variable has a significant effect on the Employee Performance of PT. Kawai Indonesia.

\subsubsection{Work Environment}

$\mathrm{T}$ count value of $3,556>\mathrm{t}$-table 1,975 with a significant value (sig.) Of $0,000<0.05$. It can be concluded that the Work Environment has a significant effect on the employees performance of PT. Kawai Indonesia.

Table 10. Simultaneous Hypothesis Test Results (Test F)

ANOVA $^{\mathrm{a}}$

\begin{tabular}{rlrrrrr}
\hline Model & & Sum of Squares & Df & Mean Square & F & Sig. \\
\hline \multirow{3}{*}{1} & Regression & 26,329 & 3 & 8,776 & 165,152 & $0,000^{\mathrm{b}}$ \\
& Residual & 8,396 & 158 & 0,053 & & \\
& Total & 34,726 & 161 & & & \\
\hline
\end{tabular}

a. Dependent Variable: KOM

b. Predictors: (Constant), GK, MO, KO

Simultaneous hypothesis test results or F test produces an F-calculated value of 165.152> 2.66 with a significant value (sig.) Of $0.000<0.05$. It can be concluded that the variables of 
work motivation, compensation, and work environment simultaneously affect the employee's performance of PT. Kawai Indonesia.

Table 13. Determination Coefficient Test Results

\begin{tabular}{c|c|c|c|c}
\hline \multicolumn{5}{c}{ Model Summary } \\
\hline Model & $\mathrm{R}$ & R Square & Adjusted R Square & $\begin{array}{c}\text { Std. Error of the } \\
\text { Estimate } \\
1\end{array}$ \\
\hline
\end{tabular}

a. Predictors: (Constant), GK, MO, KO

Obtained R-Square Adjusted value of 0.754 or $75.4 \%$. This means that the variables of work motivation, compensation, and work environment together contribute an influence of $75.4 \%$ and the remaining $24.6 \%$ are influenced by other variables outside the research model.

\section{Conclusions}

Based on the results of the Hypothesis test, several research conclusions are obtained as follows: Work motivation has a significant positive effect on the performance of employees of PT. Kawai Indonesia. Based on the results of correlation tests between dimensions it was found that the dimension of self-actualization has the most dominant relationship to employee performance. Compensation has a significant positive effect on the performance of employees of PT. Kawai Indonesia. Results Based on the results of correlation tests between dimensions, it was found that the dimensions of salary and wages have the most dominant relationship to employee performance. The work environment has a significant positive effect on the performance of the employees of PT. Kawai Indonesia.

Based on the results of the correlation test between dimensions it was found that the dimensions of the non-physical work environment had a stronger relationship to employee performance compared to the physical work environment. Thus, attention and improvement of security guarantees for employees while working becomes important. Work motivation, compensation, and work environment have a significant positive effect on the performance of employees of PT. Kawai Indonesia.

\section{References}

[1] T. Siddiqi and S. Tangem, "Impact Of Work Environment, Compensation, And Motivation On The Performance Of Employees In The Insurance Companies Of Bangladesh," South East Asia J. Contemp. Business,Economic law, 2018.

[2] D. Thavakumar and S. J. Evangeline, "The influence of Involvement and participation, compensation, communication and work-life balance on Employee Engagement: A Case of Insurance Companies in Batticaloa District," Int. J. Multidiscip. Stud., 2016, doi: 10.4038/ijms.v3i1.84.

[3] C.-R. Giroux, "The Motivation to work, by F. Herzberg, B. Mausner and B.-C. Snyderman, John Wiley \& Sons, New York, John Wiley \& Sons, 1959.," Relations Ind., 2017, doi: 10.7202/1022040ar.

[4] S. Robbins and T. Judge, Organizational Behaviour: Concepts, Controversies, Applications. 2009.

[5] M. S. P. Hasibuan, "Manajemen Sumber Daya Manusia,” Ed. Revisi Jakarta Bumi Aksara, 
2011.

[6] A. B. Saluy and Y. Treshia, "Pengaruh Motivasi Kerja, Disiplin Kerja dan Kompensasi Terhadap Kinerja Karyawan (Studi Kasus di Perusahaan PT IE),” J. Univ. Mercu Buana, 2018.

[7] A. B. Saluy, T. Musanti, and B. Mulyana, "PENGARUH PELATIHAN, MOTIVASI KERJA DAN KOMPETENSI TERHADAP KINERJA PERSONEL DI MAKOSEK HANUDNAS I.," J. Manag. Bus. Rev., 2019, doi: 10.34149/jmbr.v16i1.151.

[8] D. J. Priansa, "Manajemen Kinerja Kepegawaian dalam Pengelolaan SDM Perusahaan," in Cetakan ke-1, 2017.

[9] H. Jay and R. Barry, Principle of Operational Management. 2014.

[10] R. B. Jay, Heizer, "Prinsip-Prinsip Manajemen Operasi," Salemba Empat, 2001.

[11] A. BADAWI SALUY, B. PRAWIRA, and D. F. A. A. BUNTARAN, "The Influence of Leadership, Working Culture, and Working Environment for the Ministry of Administrative Reform and Bureaucracy,” Int. J. Bus. Econ. Aff., 2019, doi: 10.24088/ijbea-2019-45003.

[12] J. Jumingan, "ANALISIS KINERJA MANAJEMEN BERDASARKAN BALANCED SCORECARD,” J. Bisnis dan Manaj., 2017, doi: 10.20961/jbm.v15i1.4114.

[13] Jumingan and Kasidin, "The analysis of the acquisition of taxes, levies and other local revenue's effect towards original local government revenue (PAD) improvement in the city of Surakarta," Int. J. Civ. Eng. Technol., 2017.

[14] Fachreza, S. Musnadi, and M. S. A. Majid, "Pengaruh Motivasi kerja, lingkungan kerja, dan budaya organisasi terhadap kinerja karyawan dan dampaknya pada kinerja Bank Aceh Syariah di Kota Banda Aceh,” J. Magister Manaj., 2018.

[15] A. Armstrong and A. Baron, "Developing Performance Framework," in Managing performance: performance Management in action, 2004.

[16] M. Armstrong and A. Baron, "Handbook of Strategic HRM," NHRD Netw. J., 2010, doi: 10.1177/0974173920100423.

[17] A. Armstrong and A. Baron, "Performance Management: comments and issues in action," in Managing performance: performance management in action, 2005.

[18] G. Dessler, "Manajemen Sumber Daya Manusia," in Pelatihan dan Pengembangan, 2017.

[19] G. Dessler, "Personnel planning and recruiting," in A framework for human resource management, 2009. 